OPEN ACCESS

Edited by:

Zhang Chengjun,

Lanzhou University, China

Reviewed by:

Chaozhu Shu,

Chengdu University of Technology,

China

Na Tang,

Tianjin University of Science and

Technology, China

*Correspondence:

Mianping Zheng zhengmp2010@126.com

Zhen Nie

nieezhen518@163.com

Qian Wu

wuqian0516@163.com

Specialty section:

This article was submitted to Interdisciplinary Climate Studies,

a section of the journal

Frontiers in Earth Science

Received: 29 January 2022

Accepted: 21 February 2022

Published: 08 March 2022

Citation:

Ding $T$, Zheng $M$, Nie Z, Ma L, Ye C, Wu Q, Zhao $Y$, Yang $D$ and Wang $K$

(2022) Impact of Regional Climate Change on the Development of Lithium Resources in Zabuye Salt Lake, Tibet.

Front. Earth Sci. 10:865158.

doi: 10.3389/feart.2022.865158

\section{Impact of Regional Climate Change on the Development of Lithium Resources in Zabuye Salt Lake, Tibet}

\author{
Tao Ding ${ }^{1}$, Mianping Zheng ${ }^{1,2 *}$, Zhen $\mathrm{Ni}^{2 *}$, Lichun $\mathrm{Ma}^{2}$, Chuanyong $\mathrm{Ye}^{2}$, Qian $\mathrm{Wu}^{2 *}$, \\ Yuanyi Zhao ${ }^{2}$, Donghui Yang ${ }^{3}$ and Kai Wang ${ }^{4}$ \\ ${ }^{1}$ College of Geoscience and Surveying Engineering, China University of Mining and Technology (Beijing), Beijing, China, ${ }^{2}$ MNR \\ Key Laboratory of Saline Lake Resources and Environments, Institute of Mineral Resources, Chinese Academy of Geological \\ Sciences, Beijing, China, ${ }^{3}$ Hebei Earthquake Agency, The Central Station of Chengde Earthquake Observation and \\ Measurement, Chengde, China, ${ }^{4}$ School of Earth Science and Resources, China University of Geosciences, Beijing, China
}

Climate change has important implication for the ecological environment and human social activities. The Qinghai-Tibet Plateau is a sensitive area for climate change, and the lakes on the Qinghai-Tibet Plateau are known as the "guardians" of climate change. However, there are few studies on the impact of climate variations on the exploitation of lithium resources in salt lakes. In this work, the collected data from Zabuye Salt Lake Observation Station and the experimental data of brine at different temperatures were employed as the research objects to investigate the relationship between regional climate change and lithium resources in salt lakes. The results indicated that Zabuye Salt Lake had abundant solar energy resources from 1991 to 2020 with the annual average sunshine duration of $3,122.4 \mathrm{~h}$, the average annual evaporation of $2,579.07 \mathrm{~mm} / \mathrm{yr}$, and the annual average precipitation of $168.65 \mathrm{~mm} / \mathrm{yr}$. The average annual evaporation is around 15.3 times the average annual precipitation, owing to the short rainy season and the low rainfall. The phase diagram displayed that two lithium carbonate precipitation peaks clearly appeared at $25^{\circ} \mathrm{C}$, and no obvious precipitation peak appeared at $15^{\circ} \mathrm{C}$, indicating that a high-grade lithium carbonate mixed salt was prone to be formed at a higher temperature while lithium ions was more inclined to enrich in brine at a lower temperature. Therefore, Zabuye Salt Lake with the characteristics of low temperature, large temperature difference, less precipitation, strong radiation and large evaporation could be applied as unique lithium resources in the salt gradient solar pond, which would play a positive role in the development of salt lake resources.

Keywords: the Qinghai-Tibet Plateau, climate, phase diagram, salt lake, lithium extraction

\section{INTRODUCTION}

The global climate has changed significantly over the past 30 years, and such change would continue over a period of time (Fischer et al., 2018; Janos et al., 2018; Bandh et al., 2021; Ye et al., 2021). As one of the most climate-sensitive regions in the world, the Qinghai-Tibet Plateau responds rapidly to climate changes (Zhao and $\mathrm{Wu}, 2019$ ) owing to its high altitude (Liu et al., 2021) and complex topography (Yao et al., 2009). Thus, the investigation of climate changes in the Qinghai-Tibet Plateau has a certain instructive significance for the ecological environment 
and human social production. For instance, climate change influenced the vegetation growth (Hopping et al., 2018; Guo et al., 2019; Zhou et al., 2019), and intensified the glacial ablation (Chen et al., 2013), and also switched the hydrological elements such like runoffs (Guo et al., 2014).

At present, abundant researches have been conducted to reveal the impact of climate change on human social production and ecological environment development. Gudmundsson et al. (2021) analyzed the low, average and high river flows of 7,250 observation stations around the world from 1971 to 2010. The time series from the analysis and simulation models provided strong evidence that climate change would affect global river flows. Landsat 4, 5 thematic and Landsat 7 enhanced mapper images were applied in ArcGIS through the digital shoreline analysis programme (Abija, 2021), indicating that the net coastline retreat and erosion of $81,532 \mathrm{~m}, 17,519 \mathrm{~m}$ and $8,590 \mathrm{~m}$ for the Bayelsa, Rivers and Akwa Ibom States, respectively, with the erosion rates of $11.1 \mathrm{~m} / \mathrm{a}, 7.2 \mathrm{~m} / \mathrm{a}$, and $5.5 \mathrm{~m} / \mathrm{a}$, respectively. Based on the calculation results, it is recommended to formulate conventional geological scientific monitoring and climate change adaptation strategies to deal with the impact of climate change on coastline erosion. P Kurukulasuriya and Mendelsohn (2016) analyzed and predicted the impact of climate change on European agriculture with climate, soil, geography and regional socioeconomics as the single-factor evaluation using continental-scale Ricardian and averaged data from 41,030 farms in Western Europe. The results showed that European farms is slightly more sensitive to climate warming than the American farms. The contribution of European farms on climate warming would vary from +5 to $-32 \%$ by 2100 . Obviously, researchers have carried out a lot of research on the impact of climate change on agriculture, coastline erosion rate and ecological environment, and the Qinghai-Tibet Plateau was pointed out to be more sensitive to global climate change (Liu et al., 2015; Wang et al., 2021).

The average altitude of the Qinghai-Tibet Plateau exceeds $4,000 \mathrm{~m}$, known as the "roof of the world," which has an important impact on the climate, ecology and environment of the surrounding areas (Yang et al., 2016). In the past 2,000 years, the temperature change on the Qinghai-Tibet Plateau has shown a fluctuating upward trend. The average warming rate has reached $0.3 \sim 0.4^{\circ} \mathrm{C} / 10 \mathrm{a}$ in the past 50 years, being the warmest period. Observation data from 98 meteorological stations in this region indicated that the average temperature rise from 1982 to 2012 was as high as $1.9^{\circ} \mathrm{C}$, twice the global average temperature rise (Chen et al., 2014; Guo et al., 2018). A large number of lakes distributed on the Qinghai-Tibet Plateau strongly respond to the evolution of the warm and humid environment in the region, and reflect the regional climate change law under natural conditions, being a climate change-sensitive area (Wan et al., 2005; Zhang et al., 2014; You et al., 2016). As the link connecting the atmosphere, cryosphere, and hydrosphere, lakes are the lowest point of the watershed and participate in the surface water cycle through surface water accumulation and

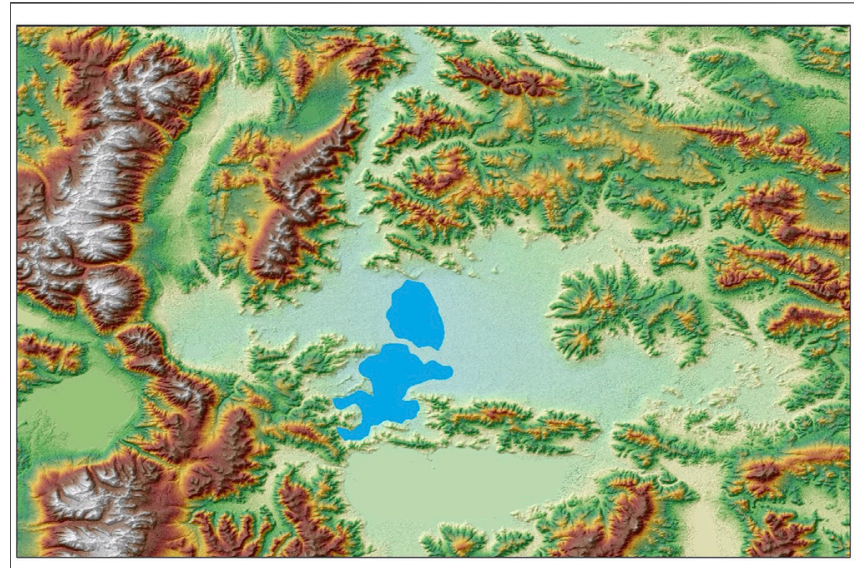

FIGURE 1 | The spatial distribution and topographic features of Zabuye Salt Lake.

evaporation, as well as groundwater collection/seepage (You et al., 2016; Lang et al., 2018; Sharma et al., 2019). Their physical, chemical and biological characteristics (ice layer characteristics, surface water temperature, etc.) are sensitive to changes in meteorological and hydrological conditions (Magnuson et al., 2000; Duguay et al., 2006; Austin and Colman, 2007), which can integrate crosslandscape climate impacts and widely regarded as the "sentinels" of climate change. The wide geographic distribution of lakes provides the capability to detect and monitor climate change on a regional, continental, hemispheric and global scale (Li et al., 2013). The trend analysis of the area change of the Hoh Xil Salt Lake was carried out through the observation data of 28 meteorological observation stations on the Qinghai-Tibet Plateau from 1989 to 2018, combined with the sensing image data gathered via the Landsat thematic mapper (Hu et al., 2021). Single-factor evaporation experiments revealed that an increase in precipitation and a decrease in annual lake evaporation over the past 30 years have resulted in an $18 \%$ increase in the total lake area. Wang et al. (2019) analyzed single-factor climate variables with the aid of the observational data from Zabuye Salt Lake and Dangxiongcuo Salt Lake in Tibet, and found that the lake water level increased by $0.032 \mathrm{~m} / \mathrm{yr}$ from 2004 to 2014 . It was believed that the main reason for the rise of lake water level was the effects of changes in seasonal climate and water supply type. Li et al. (2019) focused on the impact of climate change on lake areas and used Landsat long-term images to monitor the spatial changes of lakes from 1977 to 2015. According to the structural equation modeling with the human and natural factors, it was found that the glacier area of the QinghaiTibet Plateau decreased by $259.16 \mathrm{~km}^{2}$, while the total area of salt lakes increased by $29.8 \%$ in the past 40 years. During the period from 2000 to 2015, the expanding salt lakes submerged a large number of road facilities, posing a threat to traffic safety. This study provided a certain basis for formulating lake protection policies and the ecological construction of the Qinghai-Tibet Plateau. The above-mentioned studies 


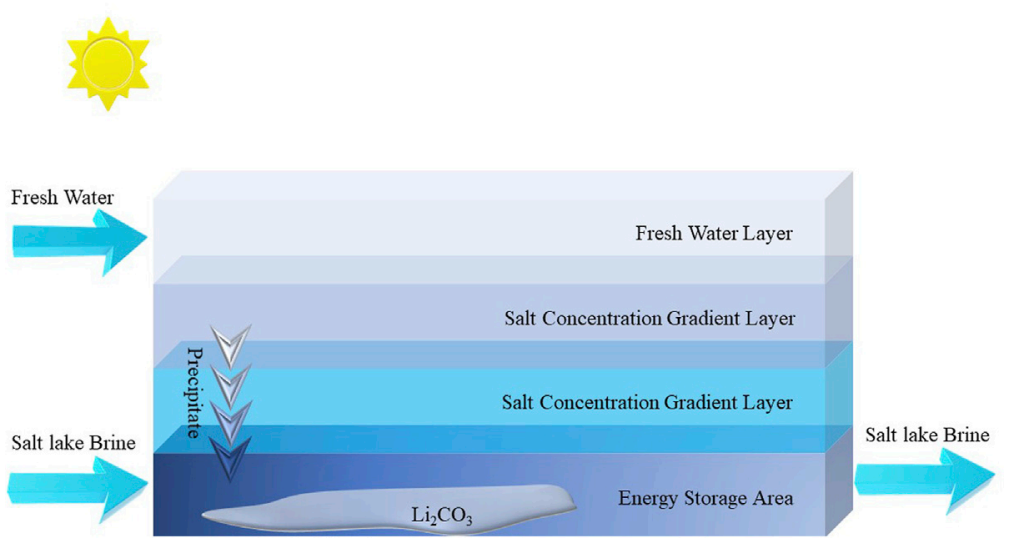

FIGURE 2 | Processes of brine production and crystallization for lithium mining in Zabuye Salt Lake.

indicated that the salt lakes on the Qinghai-Tibet Plateau exhibited a variety of responses to climate change, and it is of great scientific significance to observe the regional climate changes in the salt lake region. However, there are few reports on the impact of regional climate change on the development of lithium resources in salt lakes.

In this work, the influence of climate change on lithium mining in Zabuye Salt Lake in Tibet was investigated according to the relationship of the climate observation data and the $\mathrm{Li}^{+}$concentration of the lake in the past 30 years. Combined with the control factors in the production technology of lithium ore, the optimal conditions were analyzed for the production of lithium ore through a series of experiments, providing significant technical support for the production of lithium ore from Zabuye Salt Lake brine.

\section{BACKGROUND, MATERIALS AND METHODS}

\subsection{Research Region}

Zabuye Salt Lake, a carbonate-type saline lake, is located in Zhongba County, Ngari Prefecture, Tibet, with an arid plateau climate. The lake covers an area of $247 \mathrm{~km}^{2}$, and is divided into the northern part and the southern part (Figure 1). Zabuye Salt Lake was formed in the later stage of salt lake evolution, and its southern part has become a semi-dry salt lake with large sedimentary deposit containing dominantly lithium, potassium, boron, rubidium, cesium, bromine and other mineral elements. Among them, the reserves of lithium, boron, potassium and cesium have reached a super-high level, and the reserves of lithium carbonate has reached 1.84 million tons.

\subsection{Lithium Mining Process}

The process of extracting lithium carmine in Zabuye Salt Lake is generally divided into two steps, i.e. brine production and crystallization. In the brine production stage, lithium is rapidly enriched in salt fields to obtain a high-concentration lithium-
TABLE 1 | The main chemical composition of Zabuye salt lake brines $(\mathrm{g} / \mathrm{L})$.

\begin{tabular}{lcccccc}
\hline Elements & $\mathbf{L i}^{+}$ & $\mathbf{K}^{+}$ & $\mathbf{N a}^{+}$ & $\mathbf{S O}_{\mathbf{4}}{ }^{2-}$ & $\mathbf{C O}_{3}{ }^{2-}$ & $\mathbf{C l}^{-}$ \\
\hline Spring Brine Concentration & 1.17 & 48.1 & 122.5 & 13.1 & 33.6 & 181.3 \\
Autumn Brine Concentration & 1.05 & 40.9 & 129.6 & 38.6 & 44.2 & 156.2
\end{tabular}

containing brine. The crystallization stage mainly adopts the salt gradient solar pond technology (Ding et al., 2021), with the production process shown in Figure 2. The salt gradient solar pond consists of three functional regions. The uppermost region, called the upper troposphere, is a layer of fresh water. The middle region is called the concentration gradient layer, and the lowest region is called the energy-storage layer. In the concentration gradient layer, the specific gravity of the salt solution gradually increases with the depth of the pond, so that there is no convective movement in this layer. Therefore, the concentration gradient layer acts to prevent the upward heat of the lower layer from dissipating, so that the solar energy can be stored in the energy storage area at the bottom of the pond. The brine could be heated to $40 \sim 60^{\circ} \mathrm{C}$ in the solar pond for high-temperature crystallization, in which the precipitation was promoted to produce lithium carbonate with a grade of about $75 \%$.

\subsection{Data Sources and Methods}

The data for the experiment was collected from the Zabuye Continuous-observation Station, which was originally established in 1980 on the Zabuye Island in the middle of Zabuye Salt Lake, and later moved to the southern salt pan. The altitude of the observation station is $4,422.8 \mathrm{~m}$, and the altitude of the sensing part of the barometer is about $4,423 \mathrm{~m}$. The instrument shelter and the anemometer are 1.5 and $5 \mathrm{~m}$ from the ground, respectively. The station could record 11 items including air temperature and ground temperature, and provide dry bulbs, wet bulbs, maximum, minimum and selfrecording thermometers in the instrument shelter. The daily evaporation can be detected by a small evaporator $(\varphi 20 \mathrm{~cm})$ installed about $0.75 \mathrm{~m}$ from the ground. The precipitation can 

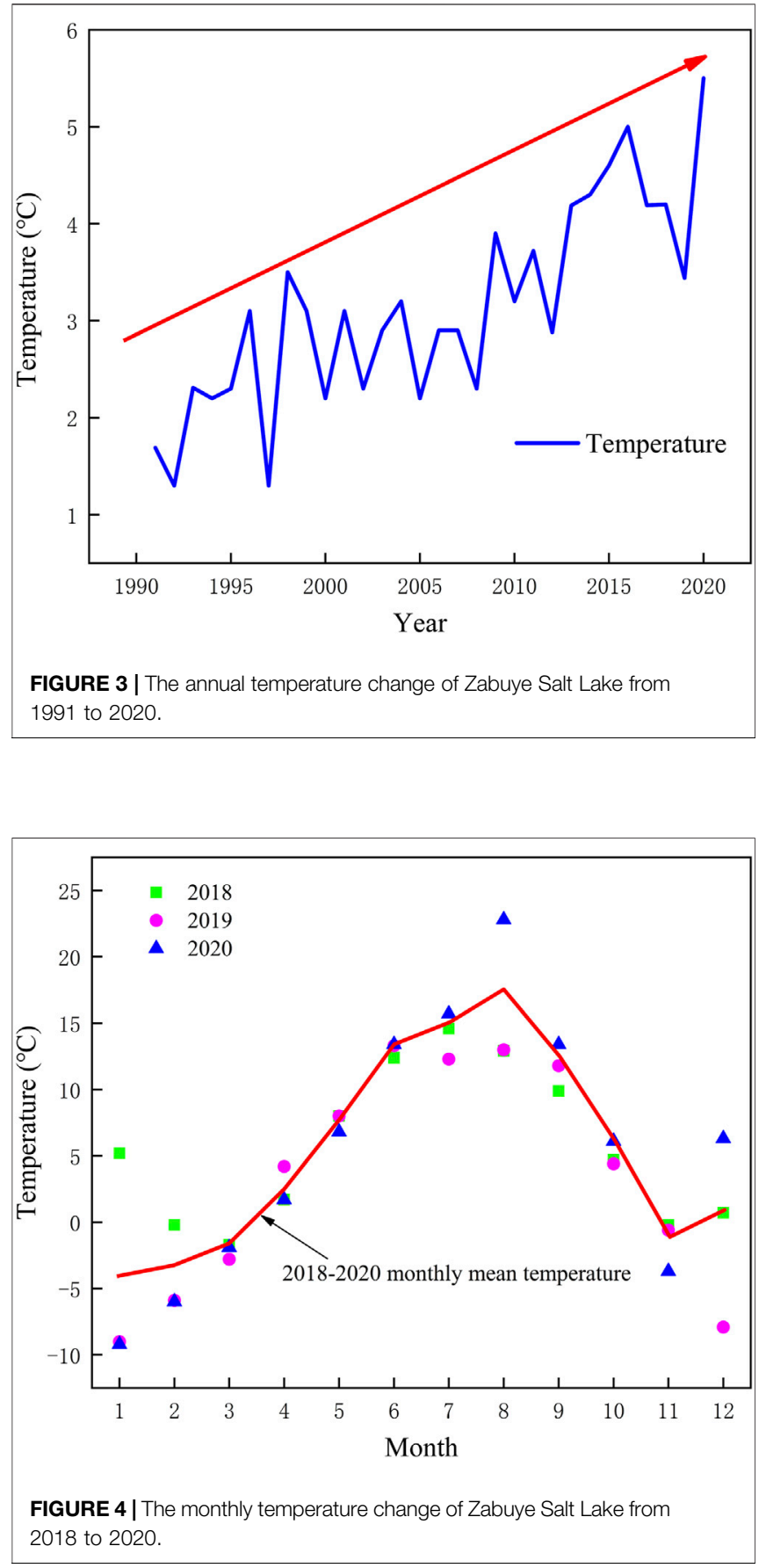

be measured with a rain gauge and a snow gauge. There are automatic recording devices for detecting sunshine hours, sunshine intensity and wind speed.

Inductively coupled plasma atomic emission spectrometry (ICP-AES, Perkin-Elmer-7000DV, USA) was employed to determine the concentrations of metal ions in the salt lake brine. To investigate brine phase chemistry, isothermal evaporation experiments on the brine of Zabuye Salt Lake were carried out at temperatures of 15 and $25^{\circ} \mathrm{C}$ in May and

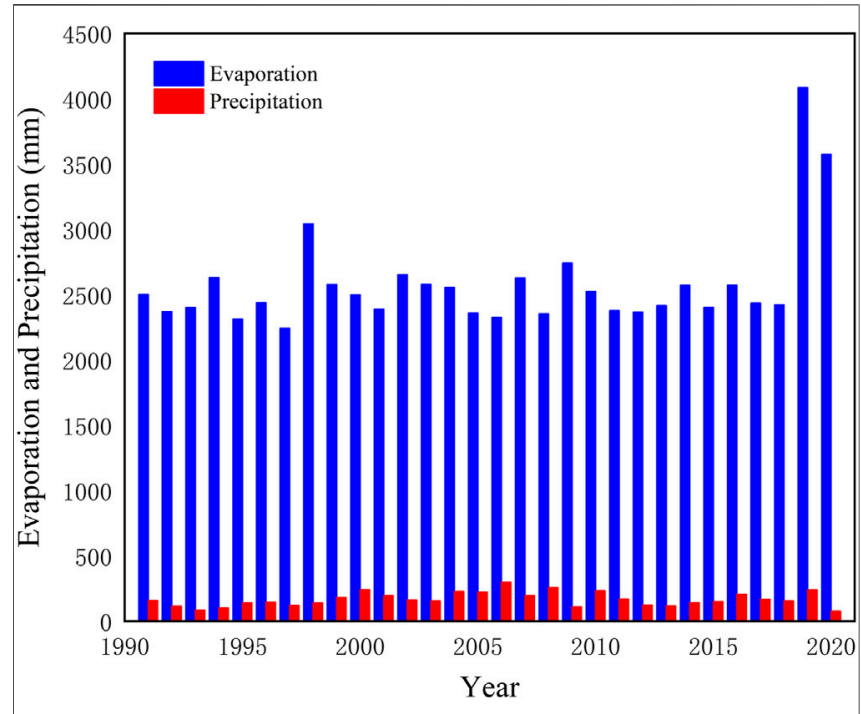

FIGURE 5 | Changes in annual precipitation and evaporation in Zabuye Salt Lake from 1991 to 2020.

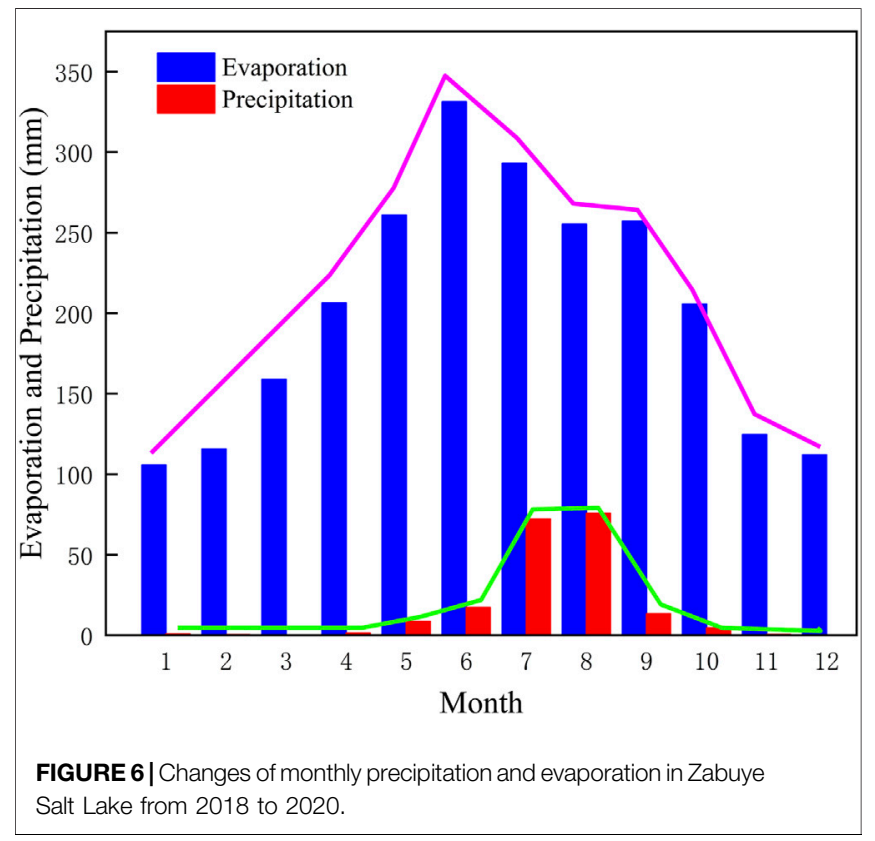

October, respectively. Table 1 for main chemical composition of Zabuye salt lake brines details. The experiments were carried out in a incubator with incandescent lamps as the heat sources. The mercury contact thermometers were applied to control the evaporation temperature $\left(15 \pm 1^{\circ} \mathrm{C}\right.$ and $\left.25 \pm 1^{\circ} \mathrm{C}\right)$ to analyze the enrichment of elements and the precipitation characteristics of minerals during the brine evaporation process. 


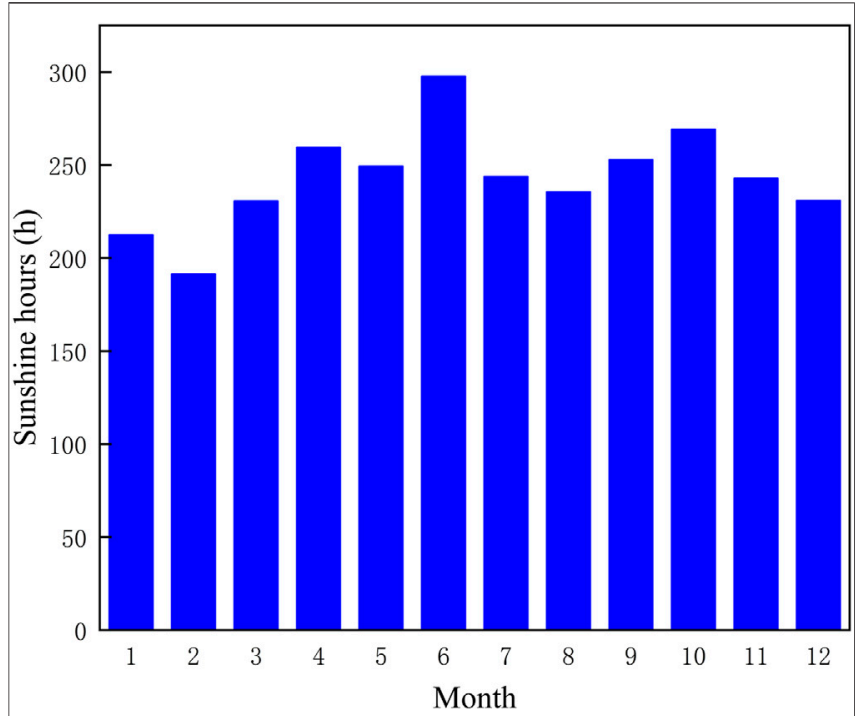

FIGURE 7 | Variation in monthly average sunshine duration in Zabuye Salt Lake from 2018 to 2020.

\section{RESULTS AND DISCUSSION}

\subsection{Regional Climate Change}

As can be seen from Figure 3, the annual average temperature of Zabuye Salt Lake showed an upward trend from 1991 to 2020, with the lowest annual average temperature of $1.3^{\circ} \mathrm{C}$ in 1992 , and the highest annual average temperature of $5.5^{\circ} \mathrm{C}$ in 2020 . The average heating rates reached $0.127^{\circ} \mathrm{C} / \mathrm{yr}$ from 1991 to 2020 , $0.051^{\circ} \mathrm{C} / \mathrm{yr}$ from 1991 to 2000 , and $0.178^{\circ} \mathrm{C} / \mathrm{yr}$ from 2011 to 2020 . reached. The above results are consistent with the reported studies (Chen et al., 2014; Guo et al., 2018; Ye et al., 2021), in which the temperature of the Qinghai-Tibet Plateau was observed to be rising and the heating rate in the past 10 years was much higher than that in the period from 1991 to 2000. The months with the monthly average temperature below zero are January, February, March, November and December in Zabuye Salt Lake. In rare cases, the average temperature in April may be lower than $0^{\circ} \mathrm{C}$. The lowest temperature of each year generally appears in January, and the highest temperature occurs in July or August, as shown in Figure 4. The monthly average maximum temperature was $22.8^{\circ} \mathrm{C}$ in August 2020 and the single-day maximum temperature was $28.5^{\circ} \mathrm{C}$ on 28 August 1992 .

Based on the monitoring data of precipitation and evaporation shown in Figure 5, the average annual evaporation of Zabuye Salt Lake from 1991 to 2020 was $2,579.07 \mathrm{~mm} / \mathrm{yr}$, and the average annual precipitation was $168.65 \mathrm{~mm} / \mathrm{yr}$. The average annual evaporation is 15.3 times the average annual precipitation. It can be seen from Figure 6 that the precipitation months in Zabuye Salt Lake were concentrated in the rainy season from early July to midSeptember. The precipitation during the rainy season accounts for more than $90 \%$ of the total annual precipitation. Therefore, the precipitation process of Zabuye Salt Lake is dominated by rainfall, with less snow and hail. The

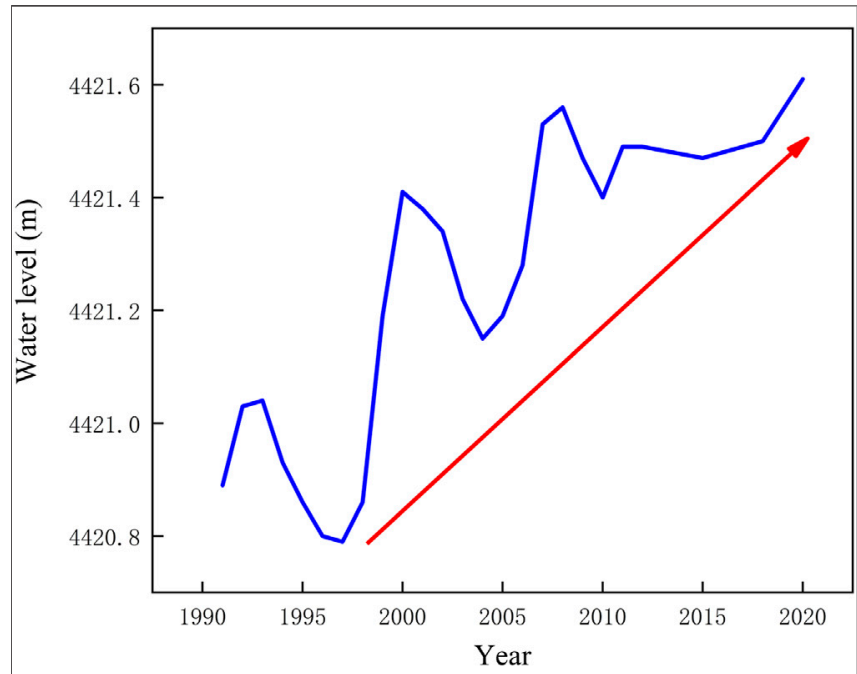

FIGURE 8 | Variation in annual water level in the North Lake of Zabuye Salt Lake from 1991 to 2020

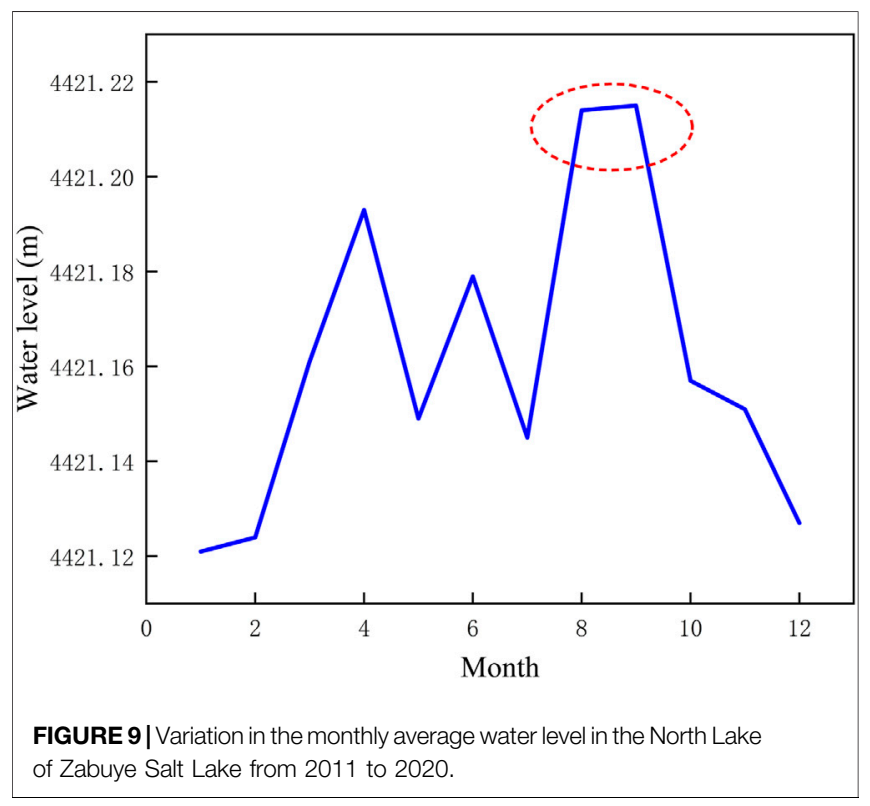

monthly variation in evaporation is similar to that of temperature, with low points appearing in January, February and December each year, and high points in June and July. Despite of the high temperature, the evaporation curve showed a distinct trough in August and September because the high air humidity greatly limited the amount of evaporation.

Zabuye Salt Lake is rich in solar energy resources with an average annual sunshine duration of $3,122.4 \mathrm{~h}$ from 2018 to 2020. It can be seen from Figure 7 that the monthly sunshine duration changes little, with the longest sunshine duration of 


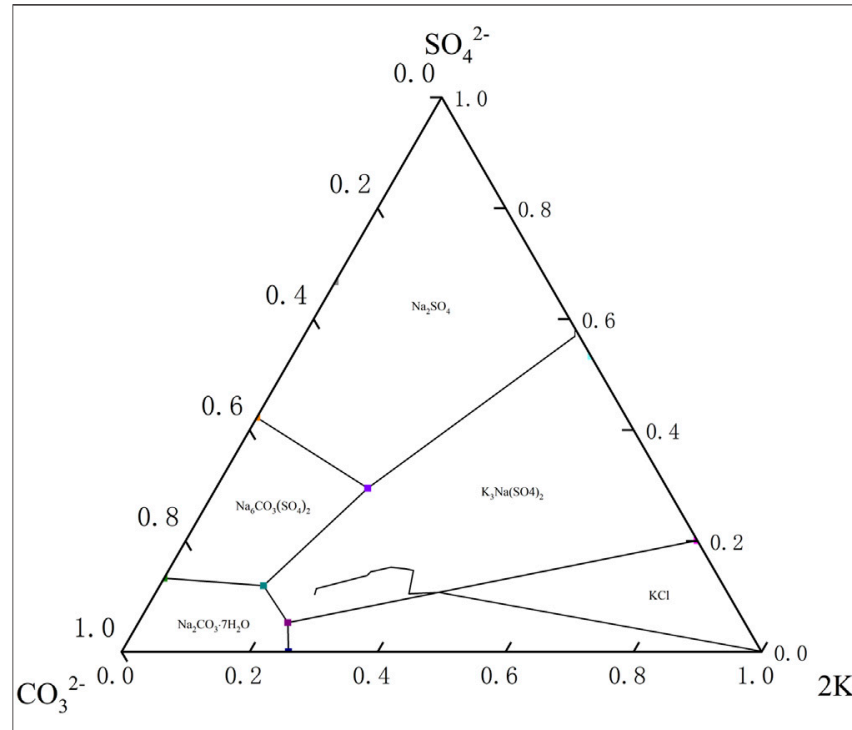

FIGURE 10 | The route diagrams of isothermal evaporation of brine taken from Zabuye Salt Lake at $15^{\circ} \mathrm{C}$ in spring.

$297.7 \mathrm{~h}$ in June. The weather in the lake district is mainly sunny or less cloudy, and rarely cloudy. The rainfall in the rainy season is mostly in the form of short-term thunderstorms. As can be seen from Figure 8, the water level of the North Lake of the Zabuye Lake shows an upward trend, corresponding to the trend of climate change (Wang et al., 2019). During the period from 1991 to 2020, the lowest annual average water level was $4,420.79 \mathrm{~m}$ in 1997, and the highest annual average water level was $4,421.61 \mathrm{~m}$ in 2020 . As shown in Figure 9, the highest point of the water level in the past 10 years appears in April, August and September, while the lowest point generally appears in January, February and December. Owing to the obvious and short rainy season in Zabuye Salt Lake, the water level always rises significantly in August and September. The ratio of evaporation to rainfall reached the maximum in May and the minimum in August. Thus, evaporation is also one of the crucial factors influencing the variance of water level. In addition, the melting of glaciers, one of the main supply of the Zabuye North Lake, is also affected by climate change. The snow and ice in the mountainous cannot melt after October, resulting in a great reduction in the water supply of the North Lake. Therefore, the water level of the salt lake displayed a slow decline after October, and reached the lowest point in January of the following year. With the rising temperature in February, the snow and ice began to melt, leading to an gradual enhancement in the water level.

\subsection{Lithium Salt Crystallization and Water Chemistry}

The isothermal evaporation experiments at 15 and $25^{\circ} \mathrm{C}$ revealed the crystallization process of salt minerals in the brine. Figures 10, 11 show the route diagrams of isothermal

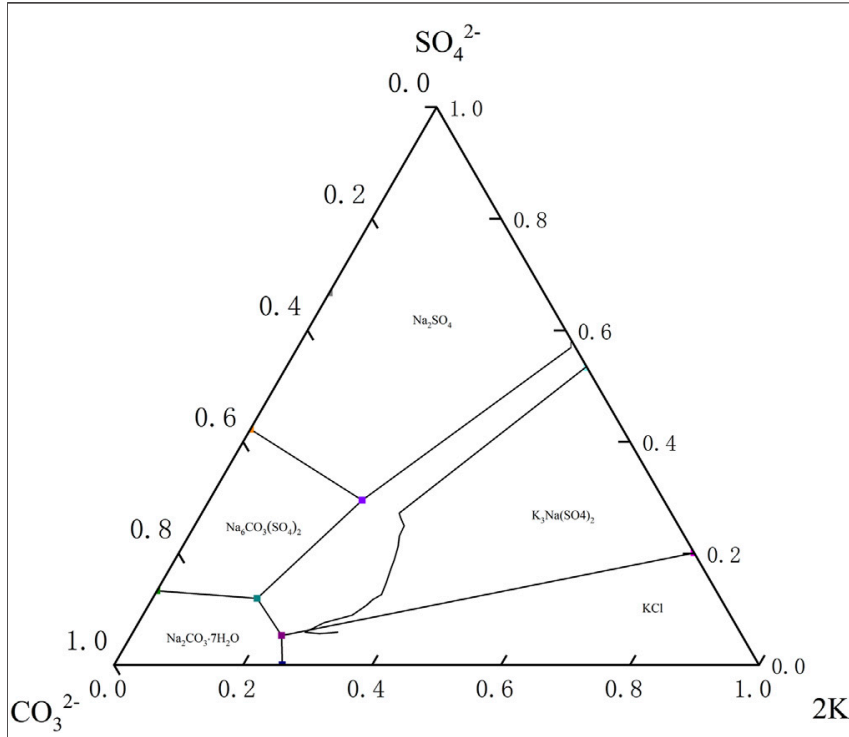

FIGURE 11 | The route diagrams of isothermal evaporation of brine taken from Zabuye Salt Lake at $25^{\circ} \mathrm{C}$ in autumn.

evaporation for brine taken from Zabuye Salt Lake at of $15^{\circ} \mathrm{C}$ brine in spring and $25^{\circ} \mathrm{C}$ brine in autumn which are taken from Zabuye Salt Lake. The metastable phase diagram of the quinary water-salt system $\mathrm{Na}^{+}, \mathrm{K}^{+} / / \mathrm{Cl}^{-}, \mathrm{CO}_{3}{ }^{2-}, \mathrm{SO}_{4}{ }^{2-}-\mathrm{H}_{2} \mathrm{O}$ was applied to describe the brine evaporation route. The original composition of brine in spring in Zabuye Salt Lake is different from that in autumn, and its composition in the system is located in the sylvite region. Therefore, the sylvite is precipitated earlier during the isothermal evaporation at $15^{\circ} \mathrm{C}$. The quinary phase diagram could be equivalent to a simplification of complex $\mathrm{Li}^{+}, \mathrm{Na}^{+}, \mathrm{K}^{+} / / \mathrm{Cl}^{-}, \mathrm{CO}_{3}{ }^{2-}, \mathrm{SO}_{4}{ }^{2-}$, $\mathrm{B}_{4} \mathrm{O}_{7}{ }^{2-}, \mathrm{HCO}_{3}{ }^{-}-\mathrm{H}_{2} \mathrm{O}$ eight system of Zabuye Salt Lake (Nie et al., 2010), and it is hard to determine the precipitation order of lithium carbonate and borax. The precipitation sequence and combination of salt minerals are relatively complicated during the experiment, as listed in Table 2. During the isothermal evaporation process at $25^{\circ} \mathrm{C}$, the precipitation sequence from the brine was halite, glaserite, lithium carbonate, trona, thermonatrite, sylvine and borax. During the isothermal evaporation process at $15^{\circ} \mathrm{C}$, the precipitation sequence of salt minerals was halite, sylvine, trona, borax, lithium carbonate, thermonatrite, natronite and glaserite.

Figure 12 shows the relationship between $\mathrm{Li}_{2} \mathrm{CO}_{3}$ and brine formation rate during isothermal evaporation at 15 and $25^{\circ} \mathrm{C}$. It can be seen that $\mathrm{Li}_{2} \mathrm{CO}_{3}$ was precipitated from the metaphase. In addition, lithium precipitation is a continuous process that occurred throughout subsequent evaporation process. During the period, the $\mathrm{Li}_{2} \mathrm{CO}_{3}$ grade in the mixed salt was relatively low, only $4 \%$ at $25^{\circ} \mathrm{C}$ and $2 \%$ at $15^{\circ} \mathrm{C}$. Two peaks for lithium carbonate precipitation clearly appeared at $25^{\circ} \mathrm{C}$, while no obvious precipitation peak was observed at $15^{\circ} \mathrm{C}$. Thus, highgrade lithium carbonate mixed salt could be obtained at a higher temperature, with more concentrated precipitation. Since Zabuye 
TABLE 2 | Salt minerals formed by isothermal evaporation of brines taken from Zabuye Salt Lake.

\begin{tabular}{|c|c|c|c|c|}
\hline Order & $\begin{array}{l}\text { Evaporation } \\
\text { rate }(\%)\end{array}$ & $15^{\circ} \mathrm{C}$ & $\begin{array}{l}\text { Evaporation } \\
\text { rate }(\%)\end{array}$ & $25^{\circ} \mathrm{C}$ \\
\hline 1 & 93.44 & $\mathrm{NaCl}$ & 95.23 & $\mathrm{NaCl}$ \\
\hline 2 & 88.25 & $\mathrm{NaCl}+\mathrm{KCl}$ & 69.81 & $\mathrm{NaCl}+\mathrm{K}_{3} \mathrm{Na}\left(\mathrm{SO}_{4}\right)_{2}$ \\
\hline 3 & 80.23 & $\mathrm{NaCl}+\mathrm{KCl}+\mathrm{Na}_{2} \mathrm{CO}_{3} \cdot \mathrm{NaHCO}_{3} \cdot 2 \mathrm{H}_{2} \mathrm{O}$ & 45.22 & $\mathrm{NaCl}+\mathrm{K}_{3} \mathrm{Na}\left(\mathrm{SO}_{4}\right)_{2}+\mathrm{Li}_{2} \mathrm{CO}_{3}$ \\
\hline 4 & 77.01 & $\mathrm{NaCl}+\mathrm{KCl}+\mathrm{Na}_{2} \mathrm{CO}_{3} \cdot \mathrm{NaHCO}_{3} \cdot 2 \mathrm{H}_{2} \mathrm{O}+\mathrm{Na}_{2} \mathrm{~B}_{4} \mathrm{O}_{7} \cdot 10 \mathrm{H}_{2} \mathrm{O}$ & 40 & $\mathrm{NaCl}+\mathrm{K}_{3} \mathrm{Na}\left(\mathrm{SO}_{4}\right)_{2}+\mathrm{Li}_{2} \mathrm{CO}_{3}+\mathrm{Na}_{2} \mathrm{CO}_{3} \cdot \mathrm{NaHCO} \cdot 2 \mathrm{H}_{2} \mathrm{O}$ \\
\hline 5 & 57.98 & $\begin{array}{l}\mathrm{NaCl}+\mathrm{KCl}+\mathrm{Na}_{2} \mathrm{CO}_{3} \cdot \mathrm{NaHCO}_{3} \cdot 2 \mathrm{H}_{2} \mathrm{O}+\mathrm{Na}_{2} \mathrm{~B}_{4} \mathrm{O}_{7} \cdot 10 \mathrm{H}_{2} \mathrm{O} \\
+\mathrm{Li}_{2} \mathrm{CO}_{3}\end{array}$ & 32.35 & $\begin{array}{l}\mathrm{NaCl}+\mathrm{K}_{3} \mathrm{Na}\left(\mathrm{SO}_{4}\right)_{2}+\mathrm{Li}_{2} \mathrm{CO}_{3}+\mathrm{Na}_{2} \mathrm{CO}_{3} \cdot \mathrm{NaHCO}_{3} \cdot 2 \mathrm{H}_{2} \mathrm{O}+ \\
\mathrm{Na}_{2} \mathrm{CO}_{3} \cdot \mathrm{H}_{2} \mathrm{O}\end{array}$ \\
\hline 6 & 37.92 & $\begin{array}{l}\mathrm{NaCl}+\mathrm{KCl}+\mathrm{Na}_{2} \mathrm{CO}_{3} \cdot \mathrm{NaHCO} \cdot 2 \mathrm{H}_{2} \mathrm{O}+\mathrm{Na}_{2} \mathrm{~B}_{4} \mathrm{O}_{7} \cdot 10 \mathrm{H}_{2} \mathrm{O} \\
+\mathrm{Li}_{2} \mathrm{CO}_{3}+\mathrm{Na}_{2} \mathrm{CO}_{3} \cdot \mathrm{H}_{2} \mathrm{O}+\mathrm{Na}_{2} \mathrm{CO}_{3} \cdot 10 \mathrm{H}_{2} \mathrm{O}\end{array}$ & 14.59 & $\begin{array}{l}\mathrm{NaCl}+\mathrm{K}_{3} \mathrm{Na}\left(\mathrm{SO}_{4}\right)_{2}+\mathrm{Li}_{2} \mathrm{CO}_{3}+\mathrm{Na}_{2} \mathrm{CO}_{3} \cdot \mathrm{NaHCO}_{3} \cdot 2 \mathrm{H}_{2} \mathrm{O}+ \\
\mathrm{Na}_{2} \mathrm{CO}_{3} \cdot \mathrm{H}_{2} \mathrm{O}+\mathrm{KCl}\end{array}$ \\
\hline 7 & 21.87 & $\begin{array}{l}\mathrm{NaCl}+\mathrm{KCl}+\mathrm{Na}_{2} \mathrm{~B}_{4} \mathrm{O}_{7} \cdot 10 \mathrm{H}_{2} \mathrm{O}+\mathrm{Li}_{2} \mathrm{CO}_{3}+\mathrm{Na}_{2} \mathrm{CO}_{3} \cdot \mathrm{H}_{2} \mathrm{O} \\
+\mathrm{Na}_{2} \mathrm{CO}_{3} \cdot 10 \mathrm{H}_{2} \mathrm{O}+\mathrm{K}_{3} \mathrm{Na}\left(\mathrm{SO}_{4}\right)_{2}\end{array}$ & 11.23 & $\begin{array}{l}\mathrm{NaCl}+\mathrm{K}_{3} \mathrm{Na}\left(\mathrm{SO}_{4}\right)_{2}+\mathrm{Li}_{2} \mathrm{CO}_{3}+\mathrm{Na}_{2} \mathrm{CO}_{3} \cdot \mathrm{NaHCO}_{3} \cdot 2 \mathrm{H}_{2} \mathrm{O}+ \\
\mathrm{Na}_{2} \mathrm{CO}_{3} \cdot \mathrm{H}_{2} \mathrm{O}+\mathrm{KCl}+\mathrm{Na}_{2} \mathrm{~B}_{4} \mathrm{O}_{7} \cdot 1 \mathrm{H}_{2} \mathrm{O}\end{array}$ \\
\hline 8 & 7.56 & $\begin{array}{l}\mathrm{NaCl}+\mathrm{KCl}+\mathrm{Na}_{2} \mathrm{~B}_{4} \mathrm{O}_{7} \cdot 10 \mathrm{H}_{2} \mathrm{O}+\mathrm{Li}_{2} \mathrm{CO}_{3}+\mathrm{Na}_{2} \mathrm{CO}_{3} \\
10 \mathrm{H}_{2} \mathrm{O}+\mathrm{K}_{3} \mathrm{Na}\left(\mathrm{SO}_{4}\right)_{2}\end{array}$ & 8.72 & $\begin{array}{l}\mathrm{NaCl}+\mathrm{K}_{3} \mathrm{Na}\left(\mathrm{SO}_{4}\right)_{2}+\mathrm{Li}_{2} \mathrm{CO}_{3}+\mathrm{Na}_{2} \mathrm{CO}_{3} \cdot \mathrm{H}_{2} \mathrm{O}+\mathrm{KCl}+ \\
\mathrm{Na}_{2} \mathrm{~B}_{4} \mathrm{O}_{7} \cdot 10 \mathrm{H}_{2} \mathrm{O}\end{array}$ \\
\hline
\end{tabular}

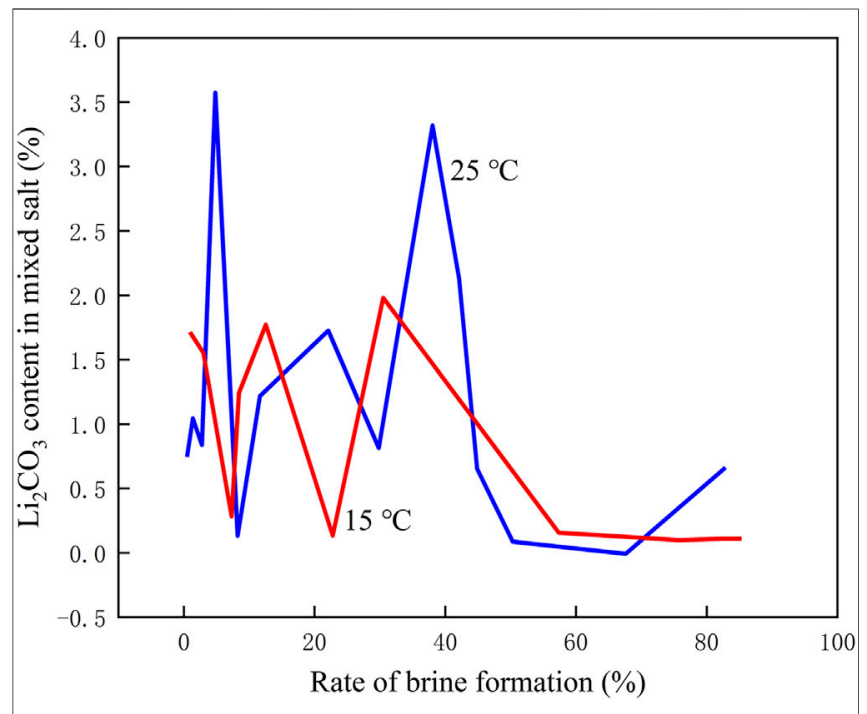

FIGURE 12 | Precipitation of lithium minerals during isothermal evaporation at 15 and $25^{\circ} \mathrm{C}$.

Salt Lake brine is dominated by carbonate type, the large amount of $\mathrm{CO}_{3}{ }^{2-}$ limited the concentration range of $\mathrm{Mg}^{2+}$ and $\mathrm{Ca}^{2+}$ in brine, resulting in a very small ratio of magnesium to lithium in Zabuye Salt Lake brine. However, the enrichment of $\mathrm{Li}^{+}$in brine was also restricted, resulting in the precipitation of lithium carbonate in most stages of the evaporation experiment. As described in Figure 13, $\mathrm{Li}^{+}$in the liquid phase could be enriched to a higher concentration at $15^{\circ} \mathrm{C}$ than at $25^{\circ} \mathrm{C}$. Therefore, it can be concluded that a low temperature was more conducive to the enrichment of lithium in Zabuye Salt Lake brine, and a high temperature favored the precipitation of lithium carbonate in Zabuye Salt Lake.

As can be seen from the temporal and spatial distribution of lithium ion concentration in the North Lake of Zabuye Salt Lake (Figure 14), the lithium ion concentration has shown a downward trend in the past 30 years from 1991 to

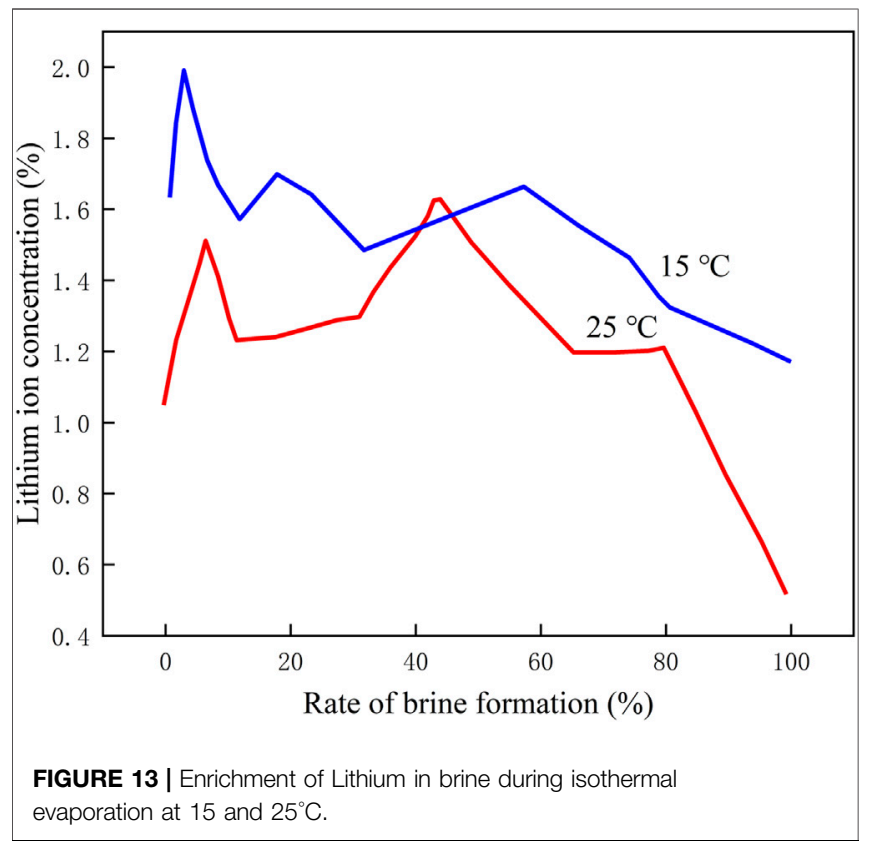

2020, and a significant decreasing trend from 2001 to 2010. This was because the lithium ore resources in Zabuye Salt Lake have been developed and utilized since 2002, and the ion concentration in the salt lake in winter is higher than that in summer. These results corresponded to the phase chemistry experiment of the brine in Zabuye Salt Lake. The lithium in Zabuye Salt Lake brine was prone to be enriched at a low temperature and predicated to be lithium carbonate at a high temperature. Thus, the lithium ions in the lake displayed a low concentration in summer.

\subsection{Lithium Resource Development}

The phase diagram experiment indicated that a high temperature is conductive to the precipitation of lithium carbonate in the salt lake, while a low temperature is favorable for the enrichment of lithium ions in the salt lake. Since Zabuye Salt Lake is located in 

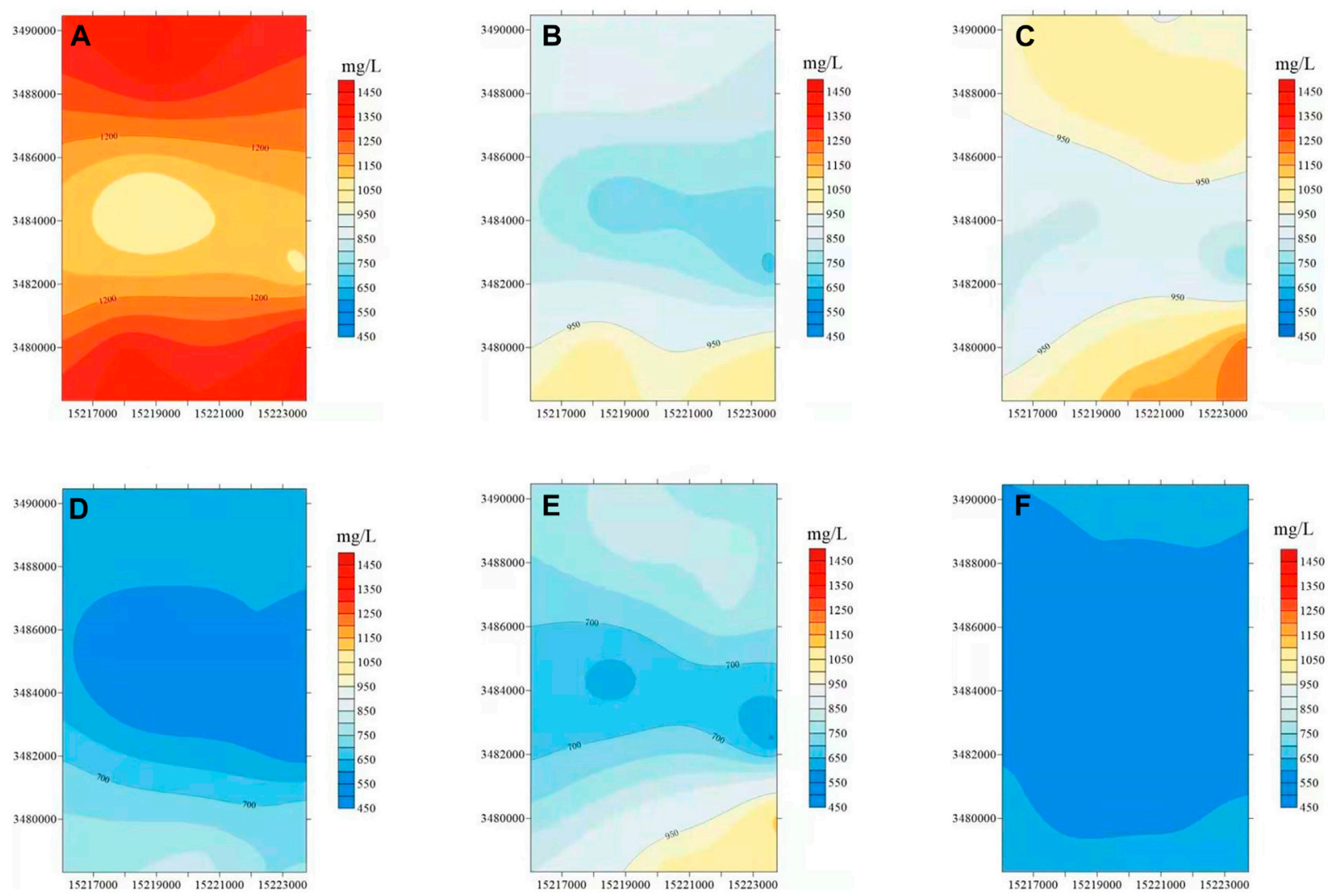

FIGURE 14 | The spatial and temporal distribution of lithium ion concentration in the North Lake of Zabuye Salt Lake [(A)1991-2000 February, (B)1991-2000 August, (C)2001-2010 February, (D) 2001-2010 August, (E)2011-2020 February, (F) 2011-2020 August).

the plateau sub-arctic climate zone and has an obvious upward trend in the annual average temperature in the past 30 years, the best period for brine storage is from November to April each year, owing to the low temperature, basically no precipitation and relatively small evaporation. All the climatic conditions mentioned above are suitable for the enrichment of lithium ions in brine. The temperature between May to October began to rise and the evaporation increased under sufficient sunshine duration. Thus, this period was more suitable for the precipitation and recovery of lithium carbonate. Since July and August are rainy seasons, precautionary preparations shall be made to prevent the entrainment and loss of the precipitated lithium carbonate mixed salt.

\section{CONCLUSION}

According to the lithium mining process as well as phase chemistry experiments, regional climate change provided several advantages for the development of lithium resources in Zabuye Salt Lake. First of all, the regional temperature of Zabuye Salt Lake has been increasing from 1991 to 2020. Observation data indicated that Zabuye Salt Lake had a large daily temperature difference above $15^{\circ} \mathrm{C}$. The climate alternated between hot and cold obviously, with a low temperature, basically no precipitation and evaporation from November to April. In accordance with the results of phase chemistry experiments, the climatic conditions during this period were suitable for the enrichment of lithium ions in brine, that is, the storage in salt gradient solar ponds. The rising temperature from May to October promoted the increased evaporation under sufficient sunshine duration, which was suitable for the precipitation and recovery of lithium carbonate based on the phase chemistry results. The mostly sunny weather throughout the year, as well as the pronounced but short rainy season with small rainfall provides a favorable conditions for the operation of salt fields. The characteristics of strong solar radiation, long sunshine duration, and large evaporation are beneficial for the production of lithium carbonate by the salt gradient solar pond method in Zabuye Salt Lake. Therefore, the rational utilization of climate change has a positive effect on the development of lithium resources in Zabuye Salt Lake. In the future, it is necessary to strengthen the field observations and surveys around Zabuye Salt Lake, and screen the optimal scenarios of future climate change. Besides, lithium ion balance model in the lake should be simulated and constructed with the aid of the 
hydrological process. The impact mechanism of climate change and human activities on lithium resources in Zabuye Salt Lake would be revealed in the future investigation, which gives support to the development and upgrading of the lithium mine industry in the lake area.

\section{DATA AVAILABILITY STATEMENT}

The original contributions presented in the study are included in the article/Supplementary Material, further inquiries can be directed to the corresponding authors.

\section{REFERENCES}

Abija, F. (2021). Relative Sea Level Rise, Coastline Variability and Coastal Erosion in the Niger Delta, Nigeria: Implications for Climate Change Adaptation and Coastal Zone Management. J. Earth Sci. Climatic Change 11 (9).

Austin, J. A., and Colman, S. M. (2007). Lake Superior Summer Water Temperatures Are Increasing More Rapidly Than Regional Air Temperatures: A Positive Ice-Albedo Feedback. Geophys. Res. Lett. 34 (6), 1-5. doi:10.1029/2006GL029021

Bandh, S. A., Shafi, S., Peerzada, M., Rehman, T., Bashir, S., Wani, S. A., et al. (2021). Multidimensional Analysis of Global Climate Change: a Review. Environ. Sci. Pollut. Res. 28 (20), 24872-24888. doi:10.1007/s11356-02113139-7

Chen, B., Zhang, X., Tao, J., Wu, J., Wang, J., Shi, P., et al. (2014). The Impact of Climate Change and Anthropogenic Activities on alpine Grassland over the Qinghai-Tibet Plateau. Agric. For. Meteorology 189-190, 11-18. doi:10.1016/j. agrformet.2014.01.002

Chen, H., Zhu, Q., Peng, C., Wu, N., Wang, Y., Fang, X., et al. (20132013). The Impacts of Climate Change and Human Activities on Biogeochemical Cycles on the Qinghai-Tibetan Plateau. Glob. Change Biol. 19 (10), 2940-2955. doi:10. $1111 /$ gcb. 12277

Ding, T., Wu, Q., Zheng, M., Nie, Z., Li, M., Peng, S., et al. (2021). Polyacrylonitrile/ Crown Ether Composite Nanofibres with High Efficiency for Adsorbing Li(I): Experiments and Theoretical Calculations. Front. Energ. Res. 9, 765612. doi:10. 3389/fenrg.2021.765612

Duguay, C. R., Prowse, T. D., Bonsal, B. R., Brown, R. D., Lacroix, M. P., and Ménard, P. (2006). Recent Trends in Canadian lake Ice Cover. Hydrol. Process. 20 (4), 781-801. doi:10.1002/hyp.6131

Fischer, H., Meissner, K. J., Mix, A. C., Abram, N. J., Austermann, J., Brovkin, V., et al. (2018). Palaeoclimate Constraints on the Impact of $2{ }^{\circ} \mathrm{C}$ Anthropogenic Warming and beyond. Nat. Geosci 11 (7), 474-485. doi:10.1038/s41561-0180196-310.1038/s41561-018-0146-0

Gudmundsson, L., Boulange, J., Do, H. X., Gosling, S. N., Grillakis, M. G., Koutroulis, A. G., et al. (2021). Globally Observed Trends in Mean and Extreme River Flow Attributed to Climate Change. Science 371 (6534), 1159-1162. doi:10.1126/science.aba3996

Guo, B., Zang, W., Yang, F., Han, B., Chen, S., Liu, Y., et al. (2019). Spatial and Temporal Change Patterns of Net Primary Productivity and its Response to Climate Change in the Qinghai-Tibet Plateau of China from 2000 to 2015. J. Arid Land 12 (1), 1-17. doi:10.1007/s40333-019-0070-1

Guo, B., Zhou, Y., Wang, S.-x., and Tao, H.-p. (2014). The Relationship between Normalized Difference Vegetation index (NDVI) and Climate Factors in the Semiarid Region: A Case Study in Yalu Tsangpo River basin of Qinghai-Tibet Plateau. J. Mt. Sci. 11 (4), 926-940. doi:10.1007/s11629013-2902-3

Guo, C., Ma, Y., Meng, H., Hu, C., Li, D., Liu, J., et al. (2018). Changes in Vegetation and Environment in Yamzhog Yumco Lake on the Southern Tibetan Plateau over Past 2000 Years. Palaeogeogr. Palaeoclimatol. Palaeoecol. 501, 30-44. doi:10.1016/j.palaeo.2018.04.005

\section{AUTHOR CONTRIBUTIONS}

$\mathrm{TD}$, major write up and review; $\mathrm{ZN}$, conception, outline, major write up, and review; LM, CY, QW, DY, and KW, critical review, content suggestions, and proofreading; MZ, critical review, content suggestions, and proofreading. YZ, sample collection.

\section{FUNDING}

The authors gratefully thank the National Natural Science Foundation of China for financial support (U20A20148).

Hopping, K. A., Knapp, A. K., Dorji, T., and Klein, J. A. (2018). Warming and Land Use Change Concurrently Erode Ecosystem Services in Tibet. Glob. Change Biol. 24 (11), 5534-5548. doi:10.1111/gcb.14417

Hu, Z., Tan, D., Wen, X., Chen, B., and Shen, D. (2021). Investigation of Dynamic lake Changes in Zhuonai Lake-Salt Lake Basin, Hoh Xil, Using Remote Sensing Images in Response to Climate Change (1989-2018). J. Water Clim. Change 12 (6), 2199-2216. doi:10.2166/wcc.2021.285

Kurukulasuriya, P., and Mendelsohn, R. (2016). A Ricardian Analysis of the Impact of Climate Change on African Cropland. Enviro Resour. Econ. 68 (1), 1-36. doi:10.1007/s10640-016-0001-y

Lang, J., Lyu, S., Li, Z., Ma, Y., and Su, D. (2018). An Investigation of Ice Surface Albedo and its Influence on the High-Altitude Lakes of the Tibetan Plateau. Remote Sensing 10 (2), 218. doi:10.3390/rs10020218

Li, H., Mao, D., Li, X., Wang, Z., and Wang, C. (2019). Monitoring 40-Year Lake Area Changes of the Qaidam Basin, Tibetan Plateau, Using Landsat Time Series. Remote Sensing 11 (3), 343. doi:10.3390/rs11030343

Li, Y., Wang, N. a., Li, Z., Zhou, X., Zhang, C., and Wang, Y. (2013). Carbonate Formation and Water Level Changes in a Paleo-lake and its Implication for Carbon Cycle and Climate Change, Arid China. Front. Earth Sci. 7 (4), 487-500. doi:10.1007/s11707-013-0392-9

Liu, J., Xin, Z., Huang, Y., and Yu, J. (2022). Climate Suitability Assessment on the Qinghai-Tibet Plateau. Sci. Total Environ. 816, 151653. doi:10.1016/j.scitotenv. 2021.151653

Liu, X.-J., Lai, Z., Madsen, D., and Zeng, F. (2015). Last Deglacial and Holocene lake Level Variations of Qinghai Lake, north-eastern Qinghai-Tibetan Plateau. J. Quat. Sci. 30 (3), 245-257. doi:10.1002/jqs.2777

Magnuson, J. J., Robertson, D. M., Benson, B. J., Wynne, R. H., Livingstone, D. M., Arai, T., et al. (2000). Historical Trends in lake and River Ice Cover in the Northern Hemisphere. Science 289 (5485), 1743-1746. doi:10.1126/science.289. 5485.1743

Mika, J., Forgo, P., Lakatos, L., Olah, A. B., Rapi, S., and Utasi, Z. (2018). Impact of $1.5 \mathrm{~K}$ Global Warming on Urban Air Pollution and Heat Island with Outlook on Human Health Effects. Curr. Opin. Environ. Sustainability 30, 151-159. doi:10.1016/j.cosust.2018.05.013

Sharma, S., Blagrave, K., Magnuson, J. J., O'Reilly, C. M., Oliver, S., Batt, R. D., et al. (2019). Widespread Loss of lake Ice Around the Northern Hemisphere in a Warming World. Nat. Clim. Chang. 9 (3), 227-231. doi:10.1038/s41558-018-0393-5

Wan, W., Long, D., Hong, Y., Ma, Y., Yuan, Y., Xiao, P., et al. (2005). A lake Data Set for the Tibetan Plateau from the 1960s, 2005, and 2014. Sci. Data 3, 160039. doi:10.1038/sdata.2016.39

Wang, C. P., Huang, M. T., and Zhai, P. M. (20212021). Change in Drought Conditions and its Impacts on Vegetation Growth over the Tibetan Plateau. ADVANCES CLIMATE CHANGE RESEARCH 12 (3), 333-341. doi:10.1016/j. accre.2021.04.004

Wang, Y., Zheng, M., Yan, L., Bu, L., and Qi, W. (2019). Influence of the Regional Climate Variations on lake Changes of Zabuye, Dangqiong Co and Bankog Co Salt Lakes in Tibet. J. Geogr. Sci. 29 (11), 1895-1907. doi:10.1007/s11442-019-1995-x

Yang, W., Guo, X., Yao, T., Zhu, M., and Wang, Y. (2016). Recent Accelerating Mass Loss of Southeast Tibetan Glaciers and the Relationship with Changes in Macroscale Atmospheric Circulations. Clim. Dyn. 47 (3-4), 805-815. doi:10. 1007/s00382-015-2872-y 
Yao, Z., Liu, J., Huang, H.-Q., Song, X., Dong, X., and Liu, X. (2009). Characteristics of Isotope in Precipitation, River Water and lake Water in the Manasarovar basin of Qinghai-Tibet Plateau. Environ. Geol. 57 (3), 551-556. doi:10.1007/ s00254-008-1324-y

Ye, B., Jiang, J., Liu, J., Zheng, Y., and Zhou, N. (2021). Research on Quantitative Assessment of Climate Change Risk at an Urban Scale: Review of Recent Progress and Outlook of Future Direction. Renew. Sust. Energ. Rev. 135, 110415. doi:10.1016/j.rser.2020.110415

You, Q., Min, J., and Kang, S. (2016). Rapid Warming in the Tibetan Plateau from Observations and CMIP5 Models in Recent Decades. Int. J. Climatol. 36 (6), 2660-2670. doi:10.1002/joc.4520

Zhang, G., Yao, T., Xie, H., Qin, J., Ye, Q., Dai, Y., et al. (2014). Estimating Surface Temperature Changes of Lakes in the Tibetan Plateau Using MODIS LST Data. J. Geophys. Res. Atmos. 119 (14), 8552-8567. doi:10. 1002/2014JD021615

Zhao, D., and Wu, S. (2019). Projected Changes in Permafrost Active Layer Thickness over the Qinghai-Tibet Plateau under Climate Change. Water Resour. Res. 55 (9), 7860-7875. doi:10.1029/ 2019wr024969

Zhen, N., Lingzhong, B., Mianping, Z., and Yongsheng, Z. (2010). Phase Chemistry Study of the Zabuye Salt Lake Brine: Isothermal Evaporation at $15^{\circ} \mathrm{C}$ and $25^{\circ} \mathrm{C}$. Acta Geologica Sinica 84 (4), 1533-1538. doi:10.1111/J.1755-6724.2010. 00150.X
Zhou, B., Li, S., Li, F., Dong, S., Ma, F., Zhu, S., et al. (2019). Plant Functional Groups Asynchrony Keep the Community Biomass Stability along with the Climate Change- a 20-year Experimental Observation of alpine Meadow in Eastern Qinghai-Tibet Plateau. Agric. Ecosyst. Environ. 282, 49-57. doi:10.1016/ j.agee.2019.06.002

Conflict of Interest: The authors declare that the research was conducted in the absence of any commercial or financial relationships that could be construed as a potential conflict of interest.

Publisher's Note: All claims expressed in this article are solely those of the authors and do not necessarily represent those of their affiliated organizations, or those of the publisher, the editors and the reviewers. Any product that may be evaluated in this article, or claim that may be made by its manufacturer, is not guaranteed or endorsed by the publisher.

Copyright (c) 2022 Ding, Zheng, Nie, Ma, Ye, Wu, Zhao, Yang and Wang. This is an open-access article distributed under the terms of the Creative Commons Attribution License (CC BY). The use, distribution or reproduction in other forums is permitted, provided the original author(s) and the copyright owner(s) are credited and that the original publication in this journal is cited, in accordance with accepted academic practice. No use, distribution or reproduction is permitted which does not comply with these terms. 